\title{
Platelets at the intersection of thrombosis and inflammation
}

Citation for published version (APA):

Karel, M. F. A. (2022). Platelets at the intersection of thrombosis and inflammation: establishing innovative methodologies. [Doctoral Thesis, Maastricht University]. Maastricht University. https://doi.org/10.26481/dis.20220222mk

Document status and date:

Published: 01/01/2022

DOI:

10.26481/dis.20220222mk

Document Version:

Publisher's PDF, also known as Version of record

\section{Please check the document version of this publication:}

- A submitted manuscript is the version of the article upon submission and before peer-review. There can be important differences between the submitted version and the official published version of record.

People interested in the research are advised to contact the author for the final version of the publication, or visit the DOI to the publisher's website.

- The final author version and the galley proof are versions of the publication after peer review.

- The final published version features the final layout of the paper including the volume, issue and page numbers.

Link to publication

\footnotetext{
General rights rights.

- You may freely distribute the URL identifying the publication in the public portal. please follow below link for the End User Agreement:

www.umlib.nl/taverne-license

Take down policy

If you believe that this document breaches copyright please contact us at:

repository@maastrichtuniversity.nl

providing details and we will investigate your claim.
}

Copyright and moral rights for the publications made accessible in the public portal are retained by the authors and/or other copyright owners and it is a condition of accessing publications that users recognise and abide by the legal requirements associated with these

- Users may download and print one copy of any publication from the public portal for the purpose of private study or research.

- You may not further distribute the material or use it for any profit-making activity or commercial gain

If the publication is distributed under the terms of Article $25 \mathrm{fa}$ of the Dutch Copyright Act, indicated by the "Taverne" license above, 


\section{Summary}

Myocardial infarction and stroke are still leading causes of death worldwide. The underlying pathology is atherosclerosis, which is considered to be orchestrated by inflammation and manifests by a build-up of plaque in the inner lining of arteries. Damage of an atherosclerotic plaque, either by plaque erosion or rupture results in exposure of thrombogenic components to the bloodstream. This in turn triggers platelet activation and subsequent thrombus formation, a process called atherothrombosis. The overall aim of this thesis was to provide novel insight in the roles of platelets at the intersection of thrombosis and inflammation by developing and implementing state of the art methods

Chapter 1 provides general background information on the processes of platelet activation, aggregation and extracellular vesicle release. In addition, in vivo and in vitro models to study (athero)thrombosis are introduced, including in vitro flow assays. This chapter also highlights novel antithrombotic agents (and combinations thereof) to prevent secondary events with (athero)thrombosis as the underlying cause.

Chapter 2 reviews published studies describing mouse models for atherothrombosis. An overview of these models was provided, including their (dis)advantages and how to select a suitable atherothrombosis model for research questions within the field of thrombosis. The models that were discussed include ultrasound, inside needle, ligation, ferric chloride and photochemical-induced plaque injury. Furthermore, the relevance of the obtained data was discussed to human pathophysiology. For this purpose, the results obtained from two different genome-wide association studies and a novel synthesis method (3D modelling) were compared. This led to the conclusion that mouse models have provided useful mechanistic insights into plaque formation, rupture and atherothrombosis. However, each outcome, regardless of the model used, should be verified in at least one additional and independent model.

In Chapter $\mathbf{3}$ we performed a study with one of the discussed mouse models for thrombosis of chapter 2. Here we assessed the effects of aspirin and rivaroxaban on thrombus formation and vascular remodelling upon temporary ligation of the mouse carotid artery. We found that ligation of the carotid artery consistently caused localised endothelial cell denudation and the formation of sub-occlusive platelet-rich thrombi. At the site of ligation, the carotid artery remodelled as evident from a reduced vessel wall extension - thus implying a local vessel stiffening - and a thickened intima-media layer. Aspirin treatment antagonized vascular stiffening and rivaroxaban treatment led to a trend towards reduced stiffening. Intima-media thickening was antagonized by both aspirin and rivaroxaban treatment. In addition, treatment with aspirin or rivaroxaban reduced the number of platelets bound per leukocyte. The mouse models were complemented with in vitro flow assays, in which we studied the effects of aspirin and/or rivaroxaban on thrombus formation, using mouse and human blood. Combined therapy of rivaroxaban and aspirin as well as rivaroxaban alone reduced thrombus contraction, size, and growth in vitro. In sum, this study shows vascular protective effects of aspirin and rivaroxaban, upon vascular injury of the mouse artery.

In Chapter $\mathbf{4}$ we introduced a novel coating technique with human atherosclerotic plaque material to study thrombosis in in vitro flow assays. Incorporating human plaque specimen as a thrombogenic surface in these assays represents the pathophysiological environment of thrombus formation upon plaque rupture. With this study, we showed that plasma treatment of glass coverslips, prior to spin coating with plaque material, resulted in a more homogenous plaque coating compared to no plasma treatment. This novel method in the field of thrombosis and haemostasis can improve the quality and reproducibility of in vitro flow experiments with plaque material.

In Chapter 5 the effects of Bruton tyrosine kinase (Btk) inhibitors ibrutinib, acalabrutinib and MK-1026 on platelet function were studied. Btk inhibitors are used to treat certain types of cancer and require lifelong treatment. However, this medication is often stopped due to side effects (including bleeding tendency), which stresses the importance of understanding and managing these side effects. We investigated the effects of the clinically used, irreversible inhibitors ibrutinib and acalabrutinib, as well as the newly developed, reversible inhibitor MK1026 (currently in phase 2 clinical trial) on platelet function and tyrosine kinase phosphorylation. Our study showed that all three inhibitors impaired glycoprotein (GP)VI and C-type lectin-like receptor 2 (CLEC-2) mediated platelet activation, aggregation and secretion in isolated platelets, but did not impair platelet adhesion in whole blood perfused over Horm type I collagen. Only ibrutinib impaired thrombus formation on surfaces co-coated with von Willebrand Factor, while variable responses were seen with CLEC-2 stimulation. We speculated that the dual inhibition of GPVI and CLEC-2 signalling by Btk inhibitors might be responsible for the increased bleeding tendency. Upon GPVI-induced tyrosine kinase phosphorylation, MK-1026 showed less off-target effects compared to ibrutinib and acalabrutinib, which might make MK-1026 a promising agent for future treatment of cancer with decreased bleeding tendency as compared to ibrutinib and acalabrutinib

We continued by investigating the role of ibrutinib in atherothrombus formation under stenotic shear conditions in Chapter 6. For this study we included cancer patients with and without ibrutinib treatment. We used our novel coating method for atherosclerotic plaque material, which was described in chapter 4 and combined it with a newly in-house developed stenotic in vitro flow chamber assay. This stenotic flow chamber had a $60 \%$ half-circular stenotic region on one side of the channel, allowing shear rate gradients around the stenotic area. We found that ibrutinib treatment in patients with haematological disorders reduced in vitro platelet deposition, thrombus size and contraction on human atherosclerotic plaque around a stenosis when compared to patients not receiving ibrutinib. Interestingly, platelet deposition on Horm type I collagen, was unaltered between patients with and without ibrutinib treatment, while 
thrombus size and contraction were reduced. The latter may suggest that ibrutinib selectively blocks platelet adhesion on plaque-collagen.

In Chapter $\mathbf{7}$ we gained new insights on the processes necessary for extracellular versicle (EV) release due to platelet activation. We found three pathways to be involved in plateletEV release: (i) integrin activation and closure on platelets, (ii) phosphatidylserine exposure on the outer membrane of platelets, and (iii) requirement of cytoskeletal rearrangements within platelets. We showed that all three pathways combined are necessary for EV release by platelets and thereby provided a better view on the signalling pathways important for vesicle release.

In Chapter $\mathbf{8}$ we studied the potential involvement of platelets and neutrophils in cerebral small vessel disease (CSVD). Individual biomarkers for platelet activation (CXCL4, CXCL7), endothelial cell activation (CX3CL1), neutrophil activation and neutrophil extracellular traps (S100A8/A9, MPO and MPO-DNA) were measured in plasma of cSVD patients and controls. MPO levels were significantly increased in plasma of CSVD patients versus controls. In addition, logistic regression and random forest analysis showed that next to MPO, MPO-DNA, CXCL7, CXCL4 and S100A8/A9 have added value in the identification of CSVD patients. In sum, we found indications for increased neutrophil activation in plasma from CSVD patients versus controls and additional value of including platelet- and endothelial activation markers to predict cSVD retrospectively.

In Chapter 9, the most important findings of this thesis are discussed in perspective of the current literature. Hereby, novel mechanistic insights that we obtained from models for experimental (athero)thrombosis, as well as the translational potential of our findings for antithrombotic therapy, are highlighted.

\section{Samenvatting}

Myocardinfarct en beroerte zijn wereldwijd nog steeds de voornaamste doodsoorzaken. Het onderliggende ziektebeeld is aderverkalking (atherosclerose), wat ontstaat door ontsteking van de vaatwand en resulteert in verdikking van de vaatwand van slagaders. Bij beschadiging van een atherosclerotische plaque worden trombogene componenten, aanwezig in de plaque, aan de bloedbaan blootgesteld. Dit leidt op zijn beurt tot activering van bloedplaatjes en daaropvolgende bloedpropvorming (trombusvorming), een proces dat atherotrombose wordt genoemd. Het doel van dit proefschrift was om nieuwe inzichten te verkrijgen in de rol van bloedplaatjes op het kruispunt van trombose en ontsteking door het ontwikkelen en implementeren van nieuwe onderzoeksmethoden.

Hoofdstuk 1 geeft algemene achtergrondinformatie over de processen die ten grondslag liggen aan bloedplaatjesactivering en extracellulaire vesicle (EV)-afgifte. Daarnaast worden in vivo en in vitro modellen om (athero)trombose te bestuderen geïntroduceerd, inclusief in vitro stromingskamers. Dit hoofdstuk belicht ook nieuwe antitrombotische medicijnen (en combinaties daarvan) om recidief trombose met (athero)trombose als onderliggende oorzaak te voorkomen.

Hoofdstuk $\mathbf{2}$ bediscussieerd gepubliceerde studies die muismodellen beschrijven voor atherotrombose. Een overzicht van deze modellen wordt gegeven, inclusief hun voor- en nadelen en handvaten voor selectie van een geschikt atherotrombosemodel voor onderzoeksvragen binnen het vakgebied van trombose. De modellen die besproken worden zijn ultrageluid, inwendige naald, ligatie, ijzerchloride en fotochemisch-geïnduceerde plaque schade. Daarnaast werd ook de relevantie van de verkregen resultaten uit muismodellen voor de menselijke pathofysiologie besproken. Hiervoor werden de resultaten van twee verschillende genoomwijde associatiestudies en een nieuwe synthese methode (3D-modellering) vergeleken. Dit leidde tot de conclusie dat muismodellen nuttige mechanistische inzichten geven in plaquevorming, -ruptuur en atherotrombose. Echter, elke uitkomst, ongeacht het gebruikte model, moet worden geverifieerd in ten minste één extra en onafhankelijk model.

In hoofdstuk $\mathbf{3}$ hebben we een studie uitgevoerd met één van de besproken muismodellen voor trombose uit hoofdstuk 2. Hier hebben we de effecten van aspirine en rivaroxaban op trombusvorming en veranderingen in de vaatwand na tijdelijke ligatie van de halsslagader van de muis onderzocht. We ontdekten dat ligatie van de halsslagader leidt tot plaatselijke beschadiging van endotheelcellen en tot de vorming van sub-occlusieve plaatjesrijke trombi. Op de plaats van de ligatie veranderde de vaatwand van de halsslagader, zoals blijkt uit een verstijving van de vaatwand en een verdikte intima-media laag. Behandeling met aspirine ging vaatwandverstijving tegen en behandeling met rivaroxaban leidde tot een trend van verminderde vaatwandverstijving. De verdikking van de intima-media werd tegengegaan door zowel behandeling met aspirine als met rivaroxaban. Bovendien verminderde de behandeling met aspirine of rivaroxaban de hoeveelheid bloedplaatjes die per leukocyt werden gebonden. De muismodellen werden aangevuld met in 
vitro stromingskamers, waarin we de effecten van aspirine en/of rivaroxaban op trombusvorming bestudeerden, met behulp van bloed van muizen en mensen. Gecombineerde therapie van rivaroxaban en aspirine, evenals rivaroxaban alleen, verminderde trombuscontractie,-grootte en groei in vitro. Kortom, deze studie laat vaatwandbeschermende effecten zien van aspirine en rivaroxaban, bij vasculair letsel van de halsslagader in de muis

In hoofdstuk 4 hebben we een nieuwe coatingtechniek geïntroduceerd met humaan atherosclerotisch plaquemateriaal om trombose te bestuderen in in vitro stromingskamers. Het incorporeren van humaan plaquemateriaal als een trombogeen oppervlak in deze kamers vertegenwoordigt de pathofysiologische omgeving van trombusvorming na een plaqueruptuur. Met deze studie toonden we aan dat plasma behandeling van dekglaasjes, voorafgaand aan coating met plaquemateriaal op een draaiende schrijf, resulteerde in een homogenere plaquecoating in vergelijking tot geen plasma behandeling. Deze nieuwe methode op het gebied van trombose en hemostase kan de kwaliteit en reproduceerbaarheid van in vitro stromingskamerexperimenten met plaquemateriaal verbeteren.

In hoofdstuk 5 werden de effecten van de Bruton tyrosine kinase (Btk) remmers ibrutinib, acalabrutinib en MK-1026 op bloedplaatjesfunctie bestudeerd. Btk-remmers worden gebruikt om bepaalde soorten kanker te behandelen en vereisen levenslang gebruik. Deze medicatie wordt echter vaak gestopt vanwege bijwerkingen (waaronder bloedingen), wat het belang benadrukt van het begrijpen en beheersen van de onderliggende oorzaak/oorzaken van deze bijwerkingen. Wij onderzochten de effecten van de klinisch gebruikte, onomkeerbare remmers ibrutinib en acalabrutinib, alsmede de nieuw ontwikkelde, omkeerbare remmer MK-1026 op bloedplaatjesfunctie. Onze studie toonde aan dat alle drie de remmers de glycoproteïne (GP) $\mathrm{VI}$ en C-type lectine-achtige receptor 2 (CLEC-2)-gemedieerde activering en aggregatie van bloedplaatjes, en het vrijzetten van bloedplaatjeseiwitten, verminderden. Echter, de hechting van bloedplaatjes aan Horm type I collageen onder stromingscondities was onveranderd. Ibrutinib, maar niet acalabrutinib en MK-1026, verhinderde trombusvorming op oppervlakken gecoat met von Willebrand Factor, terwijl variabele responsen werden gezien bij CLEC-2 stimulatie. Wij speculeerden dat de dubbele remming van GPVI en CLEC-2 geïnduceerde signaaltransductieroutes door Btk remmers verantwoordelijk zou kunnen zijn voor de verhoogde bloedingsneiging. Bij GPVI-geïnduceerde tyrosine kinase fosforylering vertoonde MK-1026 minder off-target effecten dan ibrutinib en acalabrutinib, wat MK-1026 een veelbelovend middel zou kunnen maken voor de toekomstige behandeling van kanker met een verminderde bloedingen in vergelijking met ibrutinib en acalabrutinib.

In hoofdstuk 6 hebben we de rol van ibrutinib bij atherotrombusvorming onder vaatwandvernauwende (stenotische) stromingscondities, zoals bij atherosclerose optreedt, verder onderzocht. Voor deze studie hebben we kankerpatiënten met en zonder ibrutinib behandeling geïncludeerd. We gebruikten onze nieuwe coatingmethode voor plaquemateriaal, die werd beschreven in hoofdstuk 4, en combineerden deze met een nieuw zelf ontwikkelde stenosebevattende stromingskamer. Deze stromingskamer heeft een halfcirkelvormig stenosegebied (60\%) aan één kant van het kanaal, waardoor gradiënten in afschuifsnelheid rond de stenose mogelijk waren. Wij vonden dat behandeling met ibrutinib bij patiënten met hematologische aandoeningen de aanhechting van bloedplaatjes, de trombusgrootte en de samentrekking van trombi op humaan plaquemateriaal rond een stenose in vitro verminderde in vergelijking met patiënten die geen ibrutinib kregen. Interessant is dat de aanhechting van bloedplaatjes op Horm type I collageen, dat afkomstig is van een paardenpees, onveranderd was met bloed van patiënten met en zonder ibrutinib behandeling, terwijl de trombusgrootte en contractie verminderden Dit laatste kan erop wijzen dat ibrutinib selectief de aanhechting van bloedplaatjes aan plaquecollageen blokkeert. Aanvullende studies, bijvoorbeeld met humaan type I collageen, zijn echter nodig om dit verder te onderzoeken.

In hoofdstuk $\mathbf{7}$ hebben we nieuwe inzichten verkregen in de processen die nodig zijn voor het vrijzetten van EV's als gevolg van bloedplaatjesactivatie. We vonden drie complementaire routes in EV-afgifte (i) integrineactivatie en-sluiting op de plasmamembraan van bloedplaatjes, (ii) blootstelling van fosfatidylserine op de plasmamembraan van bloedplaatjes, en (iii) veranderingen in het cytoskelet van bloedplaatjes. We toonden aan dat alle drie deze routes samen noodzakelijk zijn voor EV-afgifte door bloedplaatjes en gaven zo een beter zicht op de signaaltransductieroutes die belangrijk zijn voor het vrijzetten van blaasjes.

In hoofdstuk 8 bestudeerden we de mogelijke betrokkenheid van bloedplaatjes en neutrofielen bij cerebrale small vessel disease (CSVD). cSVD is een verzamelnaam voor problemen in de kleine bloedvaten in de hersenen. Individuele merkers voor activatie van bloedplaatjes (CXCL4, CXCL7/NAP-2), activatie van endotheelcellen (CX3CL1), activatie van neutrofielen en neutrofiele extracellulaire vallen (S100A8/A9, MPO en MPO-DNA) werden gemeten in plasma van CSVD-patiënten en controles. MPO was significant verhoogd in plasma van cSVD-patiënten versus controles. Bovendien bleek uit logistische regressie en random forest analyse dat naast MPO, ook MPO-sdDNA, CXCL7-NAP2, CXCL4 en S100A8/A9 mogelijk een toegevoegde waarde hebben bij de identificatie van CSVD-patiënten. Samenvattend vonden wij aanwijzingen voor verhoogde neutrofielactivatie in plasma van CSVD-patiënten versus controles en extra waarde van het opnemen van bloedplaatjes- en endotheelactivatiemerkers om CSVD retrospectief te voorspellen.

In hoofdstuk 9 worden de belangrijkste bevindingen van dit proefschrift besproken in he perspectief van de huidige literatuur. In het bijzonder met betrekking tot nieuwe mechanistische inzichten die zijn verkregen uit modellen voor experimentele (athero)trombose en de vertaalslag van onze bevindingen, inclusief het combineren en hergebruiken van klinisch gebruikte geneesmiddelen 